\title{
An Exploration of Leadership in Virtual Communities of Practice
}

UDC: $005.322: 316.46$

005.941

DOI: 10.7595/management.fon.2015.0027

This qualitative phenomenological research study represents the personal and professional lived experiences of midlevel leaders' effective management of virtual committees of practice (VCoP) in medical device companies in the Atlanta metro area. In-depth interviews were conducted with 15 leaders of VCoP from different medical device functional specialties. The study used a combination of the modified van Manen (1990) and van Kaam methods (Moustakas, 1994) to facilitate the analysis of the data gathered through in-depth interviews. This method served as the template for data collection and analysis. The research study revealed common themes after an analysis of data. Six emergent themes were identified: (a) empowerment, (b) communication, (c) trust, (d) encouragement/inspiration, (e) integrity, and (f) connecting with individuals. The research findings revealed a leadership model that relies on the development of genuine leaders/follower relationships to lead a VCoP effectively.

Keywords: Leadership, Virtual Communities of Practice, Management, Knowledge Based Team

\section{Introduction}

Knowledge management is the foundation of business and its purpose is to increase tacit knowledge in organizations. Researchers have examined various knowledge management methods and have acquired new insights about knowledge gained through social interactions. Kahai, Carroll, and Jestice (2007) studied various businesses and discovered the value of using the virtual world as a collaborative tool for teams. Lave and Wenger (2003), and Handley, Strudy, Fincham, and Clark (2006) discussed the concept of situated learning, which is the output from collaboration in cognitive communities. The transition of knowledge management focused on an individual's ability to learn expanded to group learning and communities of practice.

Technological advances in virtual communications and social networks create additional opportunities for communities of practice to expand beyond traditional workgroups. Functional workgroups can consist of team members located in various cities, states, and countries. Technology bridges geographic distances, and virtual communities of practice (VCoP) enable virtual workgroups to gain knowledge by using the virtual environments to reinforce an organization's collective operational knowledge (Cook-Craig \& Sabah, 2009). Communities of practice (CoP) are an important function for organizational leaders to embrace as the virtual workgroup emerges in corporations (Wenger, 2006).

Traditional leadership influences team effectiveness through the dynamic interactive influence process among members of the group (Pearce, Manz, \& Sims, 2009). Interactions in the traditional leadership approach emphasize individual abilities needed to accomplish job targets as set up by superiors (Ismail, Mohamed, Sulaiman, Mohamad, \& Yusuf, 2011). A VcoP requires leaders who have the ability to build trust, motivate, and connect and create personal bonds with individuals through technology. 


\section{Traditional Leadership Models}

\section{Transactional leadership}

The traditional approach to leadership is a relational experience between leaders and followers in which the leader expects to obtain something from the follower (Ruiz et al., 2011). The transactional approach is the relationship between the leader and the follower as an exchange based on a system of rewards and punishments (Bass \& Avolio, 1993). According to Ruggieri (2009), "The transactional leadership model offers positive reinforcement, prizes, praise, compliments and rewards when goals are reached and will utilize negative reinforcement such as punishment and reproach when errors are made or failures occur" (p. 1017). Transactional leadership is grounded in the concept of bureaucratic authority with a focus on task-oriented goals and work standards (Poulson, Smith, Hood, Arthur, \& Bazemore, 2011).

\section{Transformational leadership}

Transformational leadership includes four distinct characteristics: idealized influence, inspirational motivation, intellectual stimulation, and individualized consideration (Antonakis \& House, 2002). The idealized influence represents transformational behaviors directed at influencing the followers' perception of the leader's power, confidence and transcendent ideals (Antonakis \& House, 2002; Bass \& Riggio, 2006; Hargis et al., 2011). Inspirational motivation focuses on behaviors directed toward energizing and motivating followers to reach ambitious goals that might previously have seemed unreachable (Bass \& Riggio, 2006). Inspirational behaviors include "presenting optimistic visions for the future and creating a unified sense of mission and purpose" (Hargis et al., 2011, p. 54).

Intellectual stimulation focuses on encouraging followers to examine their assumptions and to invite innovative and creative solutions to problems (Antonakis \& House, 2002; Bass \& Riggio, 2006; Burns, 1995). Individualized consideration focuses on leadership behaviors to provide customized support of followers. Leaders who understand the needs of individual followers and encourage followers to develop to their full potential help individuals realize personal value and gain the trust and respect of followers (Avolio \& Kahai, 2003; Avolio \& Yammarino, 2002; Burns, 1995; Hicks, 2010).

\section{Community of Practice}

The collaborative process driven by knowledge management and technological advancements has led to the centralization of data as a common practice for business in the late 1980s (Goldstein \& Butler, 2010). Individual workers cultivated a sense of belonging by sharing their work experiences and by demonstrating techniques of their work, which developed into knowledge communities. Expertise itself is the outcome of interactionand is grounded in a common set of experiences, attitudes, and passions that an individual values in a community where knowledge has value (Lave \& Wenger, 2003). Early researchers of knowledge management suggested that technological enhancements creating knowledge management solutions were a way forward, but a shift occurred toward a holistic approach. A people-based knowledge management approach supported by technology shifts transformed the paradigm from individual knowledge management to knowledge communities (Bishop, Bouchlaghem, Glass, \& Matsumoto, 2008).

Community is the group of individuals for whom the domain is relevant; community includes the relationship between members and the operational boundaries of the group. A CoP is not members of a social network. The CoP involves individuals who interact and develop relationships to address problems and share knowledge (Wenger, 2006). The value of collective learning in the group lies in the competence of the group's expertise in the community.

Practice is the body of knowledge, methods, stories, and documents that members share and develop together. Practice is the focus of communities for their tasks and makes the difference to members acting as individuals and as a group (Wenger, 2006). A CoP functions by the talent, trust and collaboration in the group to allow the group to adjust to change, using the knowledge strategies of domain, community, and practice. 


\section{Network of Practice}

Networks of practice (NoP) share similarities with CoP and VCoP regarding knowledge management (Khoo \& Hall, 2013). The term network suggests that relationships among several teams is the ideal functional group expanding upon the concept of community. According to Khoo and Hall (2013), networks of practice are not ideal knowledge-sharing organizations due to network member's present information in various forms, dependent on the network size and varied member location.

Compared to the CoP or VCoP which contain a small focused knowledge based team (Wenger, 2006), the NoP is inclusive to the community of practice requiring intensive management to control participation and performance expectations (Serrat, 2010). The NoP can influence the effectiveness of a CoP because of the transmutation of broad knowledge within the network; the community of practice intensifies the need for cohesive knowledge through concentrated knowledge discussions to create community trust and inclusion (Kimble, Hildreth, \& Bourdon, 2008). Figure 1 is a visual description of the effectiveness to achieve team knowledge within a NoP, a CoP and a VCoP.

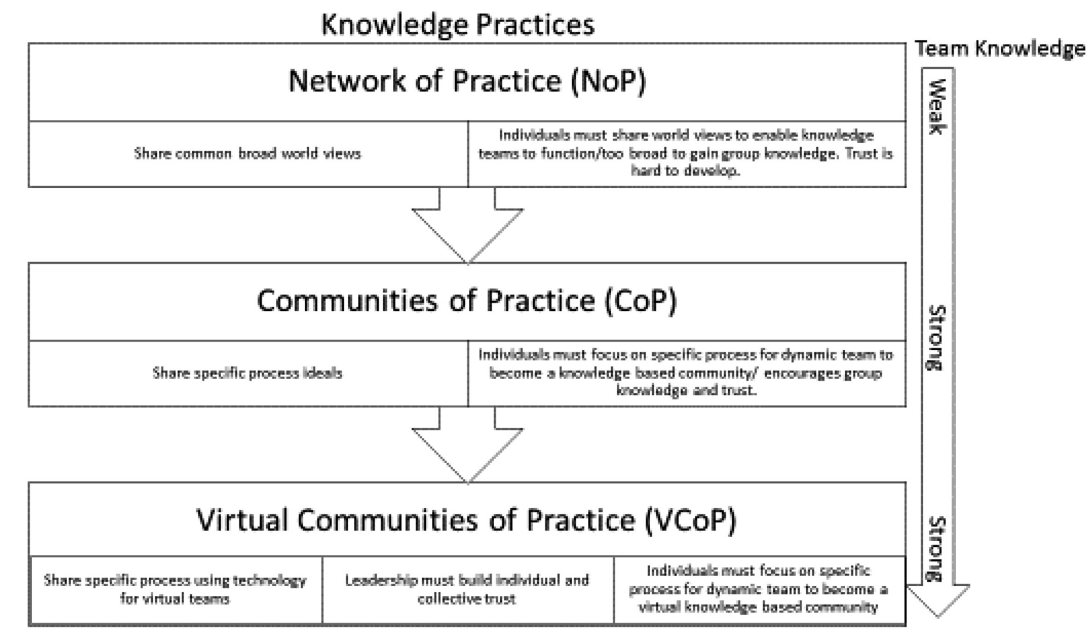

Figure 1: Comparison of knowledge practices

\section{Virtual Community of Practice (VCoP)}

The emergence of VCoPs creates challenges for leadership to lead a functional knowledge-based virtual team. The VCoP team dynamics utilizes the technological components of business, creating an immediate added value when compared to CoPs (Dubé, Bourhis, Jacob, \& Koohang, 2006). Traditional leadership models are effective in daily face-to-face activities; however, VCoPs in medical device companies require special leadership attributes that overcome leading from a distant location while building a team framework based on personal relationships. The research of medical device VCoP leadership benefits the development of current and future leader's skills leading dynamic knowledge-based teams that form VCoPs.

The benefits of VCoPs are numerous and improve an organization's knowledge management. One benefit is the development of an innovative team that achieves success through social learning. Disadvantages of VCoPs can challenge the team's effectiveness. Members of VCoPs can work in modes similar to traditional face-to-face teams; however, knowledge contributions in a virtual environment are more difficult than face-to-face communication in a traditional team structure (Fu-ren \& Hui-yi, 2013). Managing virtual teams requires abilities that include clear communication, high motivation and effective team collaboration (Kimble, 2011). In a traditional organization, transformational leaders can develop more committed, loyal, and satisfied followers (Bass \& Riggio, 2006). Transformational leadership attributes characterize the appropriate leadership model for CoPs (Ali, 2011; Carrejo, Cortez, \& Reunhartz, 2010; Sivunen, 2008). The unique nature of VCoPs requires the leader to encourage and empower team members (Ebrahim et al., 2009). 


\section{Problem Statement}

The general problem is that traditional leadership models do not support virtual team dynamics and hamper the team's ability to perform (Monalisa et al., 2008). Leaders of virtual teams face challenges to create collaboration within a team located in different regions and time zones. Ideal leaders for virtual teams begin by leading individuals and expand their leadership to the team (Kahai \& Avolio, 2008). Couto (1993) described the transformational leader as a leader who "assists a group of people to move from one stage of development to a higher one and in doing so, address and fulfill better a higher human need" (p. 103).

The specific problem is a lack of knowledge about successful leadership of VCoPs. Current literature includes reviews of leadership in remote teams; VCoPs are an emerging business function resulting from communication advancements in information technology (Gammelgaard, 2010). The VCoPs are relational without reference to specific locations (Ahuja \& Carley, 1999). The VCoPs are groups of individuals sharing a practice while in various locations and needing leaders who motivate and inspire the team members to function as a knowledge-sharing group. The qualitative phenomenological study involved examining the leadership competencies of midlevel managers leading VCoP teams in a medical device company in metro Atlanta.

\section{Purpose Statement}

The purpose of this qualitative phenomenological study was to understand the leadership qualities of a leader of VCoPs. The inquiry consisted of exploring the lived experiences of leading virtual global teams among 15 midlevel managers in medical device companies in the Atlanta metro area. The analysis method applied to the data obtained included five steps based on van Manen's (1990) and Moustakas' (1994) van Kaam method.

The data collection process consisted of four set steps: (a) allowing the participants to describe their lived leadership experience through the use of a questionnaire; (b) asking the participants to describe their feelings, mood and emotions during face-to-face interviews; (c) focusing on specific examples of an experience; and (d) searching for an individual's experience that stands out for its vividness (van Manen, 1990). Examining the lived experiences of leaders of VCoPs revealed themes that are consistent with the current literature on transformational leadership. Qualitative research is the appropriate method to investigate ethnographic, naturalistic or participant observer research (Marshall \& Rossman, 2011). Phenomenology is well suited to exploring current emerging phenomena that might be known to practitioners but whose descriptions are scarce or nonexistent in the scholarly literature (Sokolowski, 2008).

\section{Significance of the study to leadership}

The purpose of the study was to understand the different leadership styles of managers leading VCoP. The uniqueness of VCoP presents new challenges for traditional leadership methods, especially in developing the relational experience with followers in various locations. The research findings might improve leadership of teams that function as VCoPs and equip leaders with methods to overcome distance to establish relational connections.

The research was anticipated to add to existing knowledge about (a) leadership influence of dynamic knowledge-based teams, (b) skills to motivate and inspire members of virtual teams and (c) influence performance without face-to-face interaction. The study involved exploring leadership strategies used to tap into individuals' desire for personal development and connection with the leader's value system (Bass \& Riggio, 2006). The study findings identified effective leadership methods that overcame the challenges of leading in virtual environments.

\section{Nature of the Study}

The study was an exploration of virtual team leadership through the lived experience of midlevel leaders of VCoPs in medical device companies in the metro Atlanta area. The qualitative phenomenological method and design generated data from the leaders' experiences while leading VCoPs. In phenomenology, an individual's perception is the primary source of knowledge and the approach allows individuals to reflect on their acts of memory relevant to the phenomenon (Moustakas, 1994). The method and design provided data from lived experiences and supported understanding leadership in VCoPs, using idealized influence, inspirational motivation, intellectual stimulation, and individualized consideration. The phenomenological de- 
sign facilitated understanding the espondents' feelings, views of reality and special meanings they ascribe to their perceptions of reality (Rubin \& Babbie, 2010).

\section{Research Questions}

The purpose of this qualitative phenomenological study was to understand the leadership qualities of a leader of VCoPs. Van Manen (1990) described phenomenology as the study of essences. Phenomenology was the systematic attempt to uncover and describe the structures and the internal meaning structures of individual lived experiences. The following central research question was formulated to guide the study: What is the lived experience of leading virtual communities of practice teams among midlevel managers in the medical device companies in the Atlanta metro area? The following sub question was posed to narrow the focus of the research: What is the lived experience of success based on leadership style among midlevel managers in the virtual communities of practice in medical device companies in the Atlanta metro area?

\section{Research Method}

Understanding the experiences of leaders of VCoPs will generate new knowledge of leaders' influence on remote work teams. The discovery technique, which is the basis of qualitative research, provides enhanced awareness of a research topic and is well suited to promote a deeper understanding of a social setting from the perspective of the research participants (Bloomberg \& Volpe, 2008; Maxwell, 2005). According to Maxwell (2005), the five intellectual goals of qualitative research are to (a) understand the meaning of a participant's experience; (b) understand the context of a participant's actions; (c) identify unanticipated phenomena and influences; (d) understand processes, events, and actions; and (e) develop causal explanations. The research of leadership of VCoP teams was a study of the social context of relationships in remote environments and the leadership challenge to build trust, motivate, inspire and empower individuals to perform work as effectively as in face-to-face environments. Understanding a social construct required an intimate relationship with the study participants and their condition.

\section{Research Questions and Interview Questions}

The following primary research question was formulated to guide the research study: What is the lived experience of leading virtual communities of practice teams among midlevel managers in the medical device companies in the Atlanta metro area? The interview questions developed to probe for details about the research question were designed to enable the research participants to discuss the lived experience relevant to the phenomenon of leading a VCoP. The following interview questions were developed to discover common themes and patterns that emerged from the participant's responses.

1. Please share with me the story of how you came to be a VCoP team leader.

2. How would you describe your leadership style when leading VCoP teams?

3. What is the earliest recollection/experience of success as a VCoP team leader?

4. What does success mean to you when leading VCoP teams?

5. What is your definition of a successful VCoP Team?

6. How do you know when you've been successful at leading your team?

7. Think about one of your most memorable success stories in leading your team, can you please share this experience?

8. What factors do you think have contributed to your success at leading your team?

9. What attitudes have helped you lead your team?

10. What behaviors/actions have helped you lead your team?

11. What is the latest experience of successfully leading your team that you can remember?

12. Think about one of your most memorable success stories in leading your team, can you please share this experience?

13. What else would you care to discuss on leading VCoP teams before we end this interview? 


\section{Data Collection}

\section{Population}

The population of the study was midlevel VCoP leaders functioning in medical device organizations in metro Atlanta. The leaders had experience in the functional areas of sales, marketing, and operations. The population was limited to leaders of VCoPs in the United States. As shown in Table 1, the participant demographics included supervisors, managers, directors, and vice presidents.

Table 1:Study Demographic

\begin{tabular}{|l|c|c|}
\hline Study Participant Job Titles & (n) & $\%$ \\
\hline Supervisor & 2 & $13 \%$ \\
\hline Manager & 6 & $40 \%$ \\
\hline Director & 3 & $20 \%$ \\
\hline Vice President & 4 & $27 \%$ \\
\hline
\end{tabular}

\section{Emergent Themes}

The analysis of the participants' responses emerged from the collective data of the individual lived experiences as leaders of VCoP teams. The primary and secondary themes were clustered, developing the emergent themes from the collective lived experience responses. Clustering the primary and secondary themes by frequency resulted in six comprehensive emergent themes that illustrated the lived experiences of the 15midlevel medical device managers. Table 2 exhibits the emergent themes.

Table 2: Emergent Themes

\begin{tabular}{|l|r|}
\hline Themes & $\boldsymbol{f}$ \\
\hline Empowerment & 13 \\
\hline Communication & 13 \\
\hline Trust & 12 \\
\hline Encouragement/Inspiration & 11 \\
\hline Integrity & 9 \\
\hline Connecting with Individual & 9 \\
\hline
\end{tabular}

The first common theme that emerged was empowerment. Thirteen of the 15 leaders (87\%) believed that empowering individuals within the VCoP was important to achieve organizational objectives. Empowerment led to autonomy within the organization, allowing individuals to function as process owners within the VCoP.The second common theme that emerged was communication. Thirteen of the 15 leaders (87\%) believed that open, two-way communication was important to lead the VCoP effectively. Communication was an important foundation for the subsequent emerging themes and was stated in conjunction with the leader's ability to implement the organization's vision.

The third common theme that emerged was trust. Twelve of the 15 leaders (80\%) stated building trust was important to lead the VCoP. The commonality of the leader's description of trust was bi-directional; it is important for the team to trust the leader and the leader must trust the team. The fourth common theme that emerged was encouragement/inspiration. Eleven of the 15 leaders (73\%) stated individuals with the VCoP require the leader's encouragement to achieve their assigned objectives. Encouragement, inspiration and motivation required the leader to understand and connect with individual on personal and professional bases. The fifth common theme that emerged from the primary and the secondary themes was integrity. Nine of the 15 leaders $(60 \%)$ stated that integrity was a necessity for the leader and individual team mem- 


\begin{abstract}
bers. Integrity was represented as being trustworthy, honest and accountable. The sixth and final theme that emerged was connecting with the individual. Nine of 15 leaders $(60 \%)$ believed connecting with the individual was important to build professional and personal relationships with the VCoP team members. The leaders believed that a personal connection is important for the organizational success. However, the connection extends to the team member's families, expanding the personal connection and creating the foundation to achieve the preceding themes.
\end{abstract}

The participants answered the questions through the personal perspectives of leadership style experiences as VCoP managers. The manager's leadership style was clearly defined as transformational leaders from the six emergent themes: (a) empowerment, (b) communication, (c) trust, (d) encouragement/inspiration, (e) integrity, and (f) connecting with the individual. Transformational leadership includes four distinct characteristics: (a) idealized influence, (b) inspirational motivation, (c) intellectual stimulation, and (d) individualized consideration (Antonakis \& House, 2002). Idealized influence represents transformational behaviors directed at influencing the followers' perception of the leader's power, confidence and transcendent ideals (Antonakis \& House, 2002; Bass \& Riggio, 2006; Hargis et al., 2011). Inspirational motivation focuses on behaviors directed toward energizing and motivating followers to reach ambitious goals that might have seemed unreachable (Bass \& Riggio, 2006). Inspirational behaviors include "presenting optimistic visions for the future and creating a unified sense of mission and purpose" (Hargis et al., 2011, p. 54).

Intellectual stimulation focuses on encouraging followers to examine their assumptions and to invite innovative and creative solutions to problems (Antonakis \& House, 2002; Bass \& Riggio, 2006; Burns, 1995). Individualized consideration focuses on leadership behaviors to provide customized support of followers. Leaders who understand the needs of individual followers and encourage followers to develop to their full potential help individuals realize personal value and gain the trust and respect of followers (Avolio \& Kahai, 2003; Avolio \& Yammarino, 2002; Burns, 1995; Hicks, 2010). Therefore, the study results could show the participants demonstrating the attributes of transformational leadership; idealized influence, inspirational motivation, intellectual stimulation and individualized consideration as the framework of effective leaders of VCoP.

\title{
Conslusion
}

The study findings generated emergent common themes from the primary and secondary themes. The 15 participants provided their lived experience leading VCoP using a study questionnaire and 13 interview questions. The questions were designed to examine the participants' management style, measure for personal leadership success, the team's success, attributes of successful leadership and the personal qualities participants considered important to their leadership standards.

Empowerment of the team was a common theme that the VCoP leaders considered important to enable success within the VCoP. Communication was the second common theme the leaders felt was important to establish a personal connection with the VCoP. The third common theme was trust. The leaders mentioned the importance for trust to be established for leader/follower and follower/leader to achieve personal and professional growth. Encouragement/inspiration was the fourth common theme leaders stated was important to build interpersonal connection with the team. Integrity was the fifth common theme leaders felt was needed as a foundational attribute for the organization to believe in the vision, leader and team members. The sixth and final common theme was connecting with the individual. Connecting with the individual was the first step to building the relational collaborative existence of leader/follower. Without a connection to the individual, the leader could not build to the attributes of empowerment, communication, trust, encouragement and integrity.

The study results established that the effective leadership style is transformational leadership. Additionally, the study results revealed that an effective leadership of the VCoP is a collaborative endeavor that requires leadership with a genuine desire to connect with the team at the individual level. The leadership that focuses on the individual to build a collaborative team transcends the limitations and complications caused by leading a dynamic virtual team. In VCoPs, leaders must create and maintain the group's synergy, develop methods to decrease the effects of isolation from the team, and communicate through various technologies (Kirkman et al., 2002).

VCoPs present a new opportunity for leadership development and expansion. Successful transformational leadership in a virtual environment is ideal to establish interpersonal relationships to overcome distance and the lack of physical contact with the team. As Purvanova and Bono (2009) stated, transformational leaders function as relational leaders, connecting with followers on a personal level and providing mentoring to build trust between follower and leader. 


\section{REFERENCES}

[1] Antonakis, J., \& House, R. J. (2002). The full-range leadership theory: The way forward. In B. J. Avolio \& F. J. Yammarino (Eds.), Transformational and charismatic leadership: The road ahead (1st ed., pp. 334). Oxford, UK: Elsevier Science.

[2] Avolio, B. J., \& Yammarino, F. J. (Eds.). (2002). Transformational and charismatic leadership: The road ahead (1st ed.). Oxford, UK: Elsevier Science.

[3] Bass, B. M., \& Avolio, B. J. (1993). Transformational leadership: A response to critiques. In M. M. Chemers \& R. Ayman (Eds.), Leadership theory and research: Perspectives and directions (pp. 49-80). San Diego, CA: Academic Press.

[4] Bass, B. M., \& Riggio, R. E. (2006). Transformational leadership (2nd ed.). Mahwah, NJ: Lawrence Erlbaum Associates.

[5] Biklen, D. (2011). Research that matters: Qualitative research in the service of social transformation. Journal of Ethnographic \& Qualitative Research, 6(1), 1-13. Retrieved from http://www.cedarville.edu/event/eqrc/journal/journal.htm

[6] Bishop, J., Bouchlaghem, D., Glass, J., \& Matsumoto, I. (2008). Identifying and implementing management best practices for communities of practice. Architectural Engineering and Design Management, 4, 160-175. doi:10.3763/aedm.2008.0080

[7] Bloomberg, L. D., \& Volpe, M. (2008). Completing your qualitative dissertation: A roadmap from beginning to end. Thousand Oak, CA: Sage.

[8] Burns, J. M. (1995). Transactional and transforming leadership. In J. T. Wren (Ed.), The leader's companion: Insights on leadership through the ages (pp. 100-101). New York, NY: The Free Press.

[9] Carrejo, D., Cortez, T., \& Reunhartz, J. (2010). Exploring principle leadership roles within a community of practice to promote science performance of English language learners. Academic Leadership, 8(4), 12-25. Retrieved from http://www.academicleadership.org/

[10] Cook-Craig, P. G., \& Sabah, Y. (2009). The role of virtual communities of practice in supporting collaborative learning among social workers. British Journal of Social Work, 39, 725-739. doi:10.1093/bjsw/bcp048

[11] Couto, R. A. (1993). The transformation of transforming leadership. In J. T. Wren (Ed.), The leader's companion: Insights on leadership through the ages (pp. 102-107). New York, NY: The Free Press.

[12] Ebrahim, N. A., Ahmed, S., \& Taha, Z. (2009). Virtual teams: A literature review. Australian Journal of Basic \& Applied Sciences, 3, 2653-2669. Retrieved from http://www.ajbasweb.com/online.html

[13] Fu-ren, L., \& Hui-yi, H. (2013). Why people share knowledge in virtual communities?: The use of Yahoo! Kimo Knowledge + as an example. Internet Research, 23(2), 133-159. http://dx.doi.org/http://dx.doi.org/10.1108/10662241311313295

[14] Gammelgaard, J. (2010). Knowledge retrieval through virtual communities of practice. Behaviour \& Information Technology, 29, 349-362. doi:10.1080/014492909 03548406

[15] Goldstein, B. E., \& Butler, W. H. (2010). Expanding the scope and impact of collaborative planning. Journal of the American Planning Association, 76, 238-249. doi:10.1080/01944361003646463

[16] Handley, K., Strudy, A., Fincham, R., \& Clark, T. (2006). Within and beyond communities of practice: Making sense of learning through participation, identity, and practice. Journal of Management Studies, 43, 641-653. doi:10.1111/j.1467-6486.2006.00605.x

[17] Hargis, M. B., Watt, J. D., \& Piotrowski, C. (2011). Developing leaders: Examining the role of transactional and transformational leadership across contexts business. Organization Development Journal, 29(3), 51-66. Retrieved from http://www.odinstitute.org

[18] Hicks, D. A. (2010). Globalization. In G. R. Hickman (Ed.), Leading organizations: Perspectives for a new era (2nd ed., pp. 14-20). Thousand Oaks, CA: Sage.

[19] Ismail, A., Mohamed, H. A.-B., Sulaiman, A. Z., Mohamad, M. H., \& Yusuf, M. H. (2011). An empirical study of the relationship between transformational leadership, empowerment and organizational commitment. Business \& Economics Research Journal, 2(1), 89-107. Retrieved from http://www.berjournal.com/

[20] Kahai, S. S., \& Avolio, B. J. (2008). E-leadership. In G. R. Hickman (Ed.), Leading organizations: Perspectives for a new era (2nd ed., pp. 239-244). Thousand Oaks, CA: Sage.

[21] Kahai, S. S., Carroll, E., \& Jestice, R. (2007). Team collaboration in virtual worlds. Database for Advances in Information Systems, 38(4), 61-69. doi:10.1145/1314234.1314246

[22] Khoo, M., \& Hall, C. (2013). Managing metadata: Networks of practice, technological frames, and metadata work in a digtial libary. Information and organization, 23(2), 81-106. 
[23] Kimble, C. (2011). Building effective virtual teams: How to overcome the problems of trust and identity in virtual teams. Global Business and Organizational Excellence, 30(2), 6-15. doi:10.1002/joe.20364

[24] Kimble, C., Hildreth, P., \& Bourdon, I. (Eds.). (2008). Learning communities are not mushrooms. Communities of practice: creating learning environments for educators, Volume 2. United States of America: Information Age .

[25] Kirkman, B. L., Rosen, B., Gibson, C. B., Tesluk, P. E., \& McPherson, S. O. (2002). Five challenges to virtual team success: Lessons from Sabre, Inc. Academy of Management Executive, 16(3), 67-79. doi:10.5465/AME.2002.8540322

[26] Lave, J., \& Wenger, E. (2003). Situated learning: Legitimate peripheral participation. New York, NY: Cambridge University Press.

[27] Marshall, C., \& Rossman, G. B. (2011). Designing qualitative research (5th ed.). Thousand Oaks, CA: Sage.

[28] Maxwell, J. A. (2005). Qualitative research design: An interactive approach (2nd ed.). Thousand Oaks, CA: Sage.

[29] Monalisa, M., Daim, T., Mirani, F., Dash, P., Khasmis, R., \& Bhusari, V. (2008). Managing global design teams. Research Technology Management, 51(4), 48-59. Retrieved from http://www.iriinc.org/webiri/rtm.cfm

[30] Moustakas, C. (1994). Phenomenological research methods. Thousand Oaks, CA: Sage.

[31] Pearce, C. L., Manz, C. C., \& Sims, H. P. (2009). Where do we go from here? Is shared leadership the key to team success?. Organizational Dynamics, 38, 234-238. doi:10.1016/j.orgdyn.2009.04.008

[32] Poulson, R. L., Smith, J. T., Hood, D. S., Arthur, C. G., \& Bazemore, K. F. (2011). The impact of gender on preferences for transactional versus transformational professorial leadership styles: An empirical analysis. Review of Higher Education \& Self-Learning, 3(11), 58-70. Retrieved from http://www.intellectbase.org

[33] Purvanova, R. K., \& Bono, J. E. (2009). Transformational leadership in context: Face-to-face and virtua teams. The Leadership Quarterly, 20, 343-357. doi:10.1016/j.leaqua.2009.03.004

[34] Rubin, A., \& Babbie, E. R. (2010). Essential research methods for social work (2nd ed.). Belmont, CA: Brooks/Cole.

[35] Ruggieri, S. (2009). Leadership in virtual teams: A comparison of transformational and transactional leaders. Social Behavior \& Personality, 37, 1017-1021. Retrieved from http://www.sbp-journal.com/

[36] Ruiz, P., Ruiz, C., \& Martinez, R. (2011). Improving the leader-follower relationship: Top manager or supervisor? The ethical leadership trickle-down effect on follower job response. Journal of Business Ethics, 99, 587-608. doi:10.1007/s10551-010-0670-3

[37] Serrat, O. (2010). Building networks of practice. Asian Devleopment Bank. Retrieved from http://digitalcommons.ilr.cornell.edu/cgi/viewcontent.cgi?article $=1122 \&$ context $=$ intl

[38] Sivunen, A. (2008). The communication of leaders in virtual teams: Expectations and their realisation in leader's computer-mediated communication. International Journal of Work Innovation, 2(1), 47-60. Retrieved from http://www.inderscience.com/jhome.php?jcode $=$ ijwi

[39] Sokolowski, R. (2008). Phenomenology of the human person. New York, NY: Cambridge University Press.

[40] van Manen, M. (1990). Researching lived experience: Human science for an action sensitive pedagogy. Albany, NY: State University of New York.

[41] Wenger, E. (2006). Communities of practice a brief introduction. Retrieved from http://www.ewenger.com/theory/index.htm 


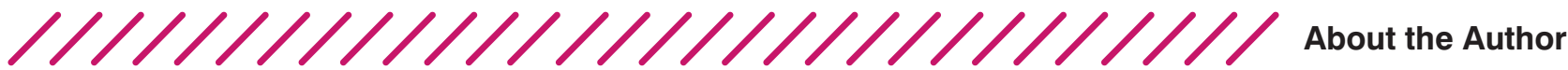

\author{
John T. Chrisentary \\ University of Phoenix \\ dr.jchrisentary@gmail.com
}

Dr. Chrisentary Jr., D.M.functions within the medical device industry, creating knowledge-based dynamic global support teams. His continues to develop leaders and teams to function as agile, adaptive, purposeful and successful organizations that build value at the organizational and individual levels.

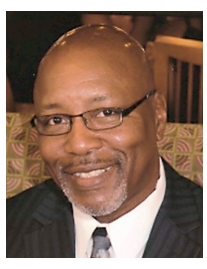

Dennis E. Barrett

University of Pittsburgh and University of Phoenix denbarrett@verizon.net

Dr. Barrett Ph.D.is a retired School Superintendent and is currently serving as a doctoral advisor at the University of Phoenix. 